\title{
Figures and graphs
}

\section{Figures}

1 Embroidered front cover for Bible and Book of Common Prayer The handiwork - to embellish a 1607 publication (STC 16332) remains unattributed. 64.101.1291, gift of Irwin Untermyer, 1964: Metropolitan Museum of Art, New York. Public domain.

2 Embroidered front cover for Bible Anne Cornwallis Leigh's needlework for The Bible: that is, the Holy Scriptures conteined in the Olde and Neme Testament (Amsterdam, 1639). PML 17197.1, purchased by Pierpont Morgan, 1910: The Morgan Library \& Museum, New York. [www.themorgan.org/ bindings/103103]

3 Publius Lentulus's letter

Anon., Publius Lentulus his report to the Senate of Rome concerning Fesus Christ (?London, 1700?, Wing L1095D). BrSides By6 1680: Beinecke Rare Book and Manuscript Library, Yale University.

4 James Nayler stigmatised Ephraim Pagitt, Heresiography (London, 1662, Wing P182), p. 244. 178- 665q: by permission of the Folger Shakespeare Library.

5 Natal horoscope for Frescheville Holles (8 June 1642-28 May 1672) John Gadbury, Collectio geniturarum (London, 1662, Wing G80), p. 159. Nkk74 +662g: Beinecke Rare Book and Manuscript Library, Yale University.

6 Interpretive schema for natal horoscope John Gadbury, Genethlialogia (London, 1658, Wing G84), p. 36. Nkk74 +662g: Beinecke Rare Book and Manuscript Library, Yale University.

7 South American natives

Sir John Narbrough, 'The land of Patagonia' (detail), c.1670.

Maps K.Top. 124.84.8: (C) The British Library Board. [https:// imagesonline.bl.uk/] 
8 The Hollanders unmasked

The Dutch boare dissected, or a description of Hogg-Land (1665).

1868,0808.3278: (C) The Trustees of the British Museum.

9 Body ideal

Richard Saunders, Physiognomie and chiromancie, metoposcopie, the symmetrical proportions and signal moles of the body, fully and accurately handled; with their natural-predictive-significations (London, 1653, Wing S754), p. 262. Krq7 +653s: Beinecke Rare Book and Manuscript Library, Yale University.

\section{Graphs}

1 Distribution of references to skin colour in London newspaper advertisements, 1651-1700. Data compiled by author.

2 Distribution of references to skin colour in British newspaper advertisements, 1701-50. Data compiled by author.

3 London advertisements with comment on skin, versus without, 1651-1750. Data compiled by author.

4 Distribution of references to skin colour in American advertisements, 1701-50. Data compiled by author. 